\title{
Hydrogeochemical Indices for the Prospecting of Hydrocarbon and Native Sulphur Deposits
}

\author{
Adil K. Jamil \\ Department of Geology \\ College of Science \\ Baghdad University
}

(Received 18/10/2001 ; Accepted 29/6/2002)

\begin{abstract}
Two hydrogeochemical indices are presented namely: the balance of sulfate (B.S) and the index of aeration (I.A) and may be used as geochemical tools to give important information that indicate the presence of good prospects of oil and native sulphur deposits. The B.S and I.A are calculated from the hydrochemical data of natural waters (formation waters, oil field brines, sulphurous springs, ...etc) that are associated with these deposits. For hydrocarbon deposits the B.S values were negative and ranged from few to several thousands, while I.A values were positive and ranged from zero to 10 for excellent prospects to 100 or to 1000 for less important prospects. For native sulphur deposits, both the B.S and I.A values were positive and ranged from few hundreds to thousands. Many examples of oil field waters and sulphurous springs from Iraq were examined and gave results of high positive significance.
\end{abstract}

\section{معالمات هيروجيوكيميائية النحري عن التوضهل الهيروكرونية والكبريت الحر}

\section{الملغص}

يقدم البحث الثنين من المعلملات الهيدروجيوكيميائية وهما: معلمل توازن الكبريتات (B.S) ومعلمل

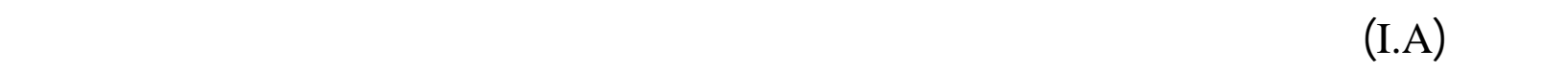
التوضعكت الهيدروكربونية والكبريت الحر. ويجسب لكل من B.S و I.A من المعلوملت الهيدروكيميائي ة

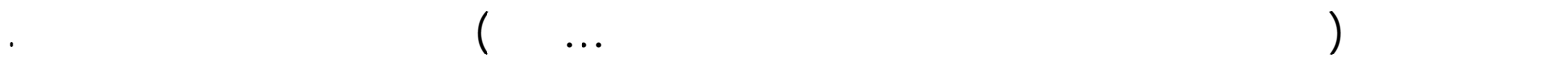

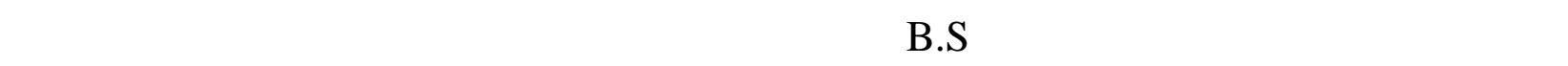

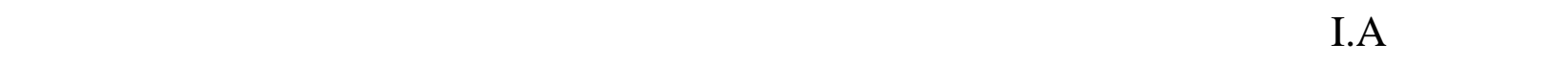

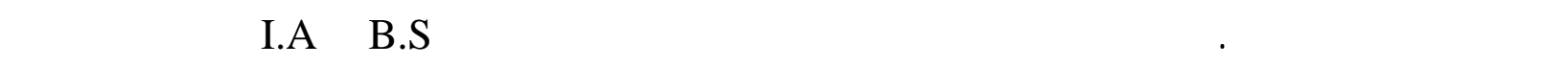

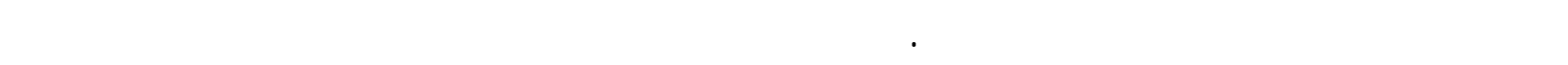
عيون كبريتية من العراق والتي عند طبيق هذه المعلملات عليها اعطت نتائج ليجابية معتبرة جدا. 


\section{INTRODUCTION}

The hydrochemical composition of subsurface waters are used by the petroleum industry as a criterion for subsurface exploration (oil and natural gas) deposits, and the

hydrochemical features of a basin may reflect the hydrodynamics of petroleum accumulation. Similarly, in the geochemical exploration of subsurface ore deposits.

As for oil field waters, several classification systems were proposed such as those of Sulin (1946), Chebotarev (1955), Bojarski`s (1970) modification of Sulin`s system

and Dabrowski (1972) where hydrochemical ratios such as $\mathrm{Na} / \mathrm{Cl}$, expressed in milligram-equivalents, were used as hydrochemical indicators of hydrocarbons. Oil field brines with $\mathrm{Na} / \mathrm{Cl}$ equal to $0.75-0.65,0.65-0.50$ and less than 0.5 characterizes favorable conditions for the preservation of hydrocarbon deposits, in particular those of less than 0.5 which are considered one of the most likely areas where hydrocarbons

are accumulated (Collins, 1975).

Moreover, according to Buljan (1962 and 1963), every natural water, including contact waters (oil field brines), can be characterized by two important properties, namely: 1.The balance of sulphate (B.S) which equals the loss of sulphate during the diagenesis of water.

2.The index of aeration (I.A) which indicates the degree of aeration of the water. These two indices have numerical values which can be calculated for every water from the results of a routine chemical analysis.

The aim of this paper is to introduce these two indices, their method of calculation and to examine and test their application on various natural waters in Iraq that are associated with hydrocarbon and native sulphur deposits.

\section{CALCULATION OF (B.S) AND (I.A)}

For natural waters $\mathrm{Cl}^{-1}$ and $\mathrm{SO}_{4}^{-2}$ are perhaps the most important pair of ions. The chloride ion is the least affected ion by geochemical processes while the sulphate is the most affected.

Regarding sea water for each quantity of $19.010 \mathrm{gm} . \mathrm{Kgm}^{-1} \mathrm{Cl}^{-1}$ there is a corresponding quantity of $2.649 \mathrm{gm} . \mathrm{Kgm}^{-1} \mathrm{SO}_{4}^{-2}$. In any type of water, the chloride content will therefore permit the calculation of the theoretical content of sulphate, $\left(\mathrm{SO}_{4}{ }^{-2}\right)_{\mathrm{t}}$ that corresponds the quantity of chloride (+bromide) in that water (Buljan, 1963).

$$
\begin{array}{cc}
\text { For sea water (S.W): } & \frac{\mathrm{SO}_{4}}{\mathrm{Cl}}=\frac{2.649}{19.010}=0.1394 \\
& \frac{\left(\mathrm{SO}_{4}\right)_{S . W}}{(\mathrm{Cl})_{\text {S.W }}}=\frac{\left(\mathrm{SO}_{4}\right)_{t}}{(\mathrm{Cl})_{\text {water }}}
\end{array}
$$

Therefore, the theoretical sulphate content for natural waters equals to:

$$
\left(\mathrm{SO}_{4}\right)_{t}=0.1394 x(\mathrm{Cl})_{\text {water }}
$$


And:

$$
\begin{array}{r}
\text { B.S }=\left(\mathrm{SO}_{4}\right)_{\text {water }}-\left(\mathrm{SO}_{4}\right)_{t} \\
I . A=\frac{\left(\mathrm{SO}_{4}\right)_{\text {water }}}{\left(\mathrm{SO}_{4}\right)_{t}} \times 100
\end{array}
$$

From these two equations it is evident that for sea water: B.S=zero and I.A=100.

\section{HYDROCHEMICAL DATA}

To fulfill the aim of this paper, hydochemical data were selected from the geochemical literature, which included (Fig.1): 1.Oil field waters from oil fields in Iraq, very well known for their superior reserves and production of oil, namely Zubair reservoir (Cretaceous) of Zubair (Zb), South

Rumaila (Ru) and North Rumaila (R) oil fields (Table 1). 2.Natural sulphurous springs at Mishraq sulphur mine, North Iraq, well known for its high reserve and production of native sulphur (Table 2). 3.Oil field waters from not yet developed oil fields in Iraq of different reservoirs, namely: Luhais (LU), Suba (SU), West Qurna (WQ), Nasiriyah (NS), Hemrin (HM) and Jabal Qand (JQ) (Table 3).

4.Sulphurous springs at Qiyara, Fat ha, Hit, Kubisa and Mosul (Ain Kibrit and Hammam Al-Alil) (Table 4). 
Fig. 1: location map of examined oil fields and natural springs.

Table 1: Hydrochemical data of Zubair reservoir (Cretaceous), S. Rumaila and N. Rumaila oil fields (Ref.: Jamil, 1975, 1978).

\begin{tabular}{|c|c|c|c|c|c|c|}
\hline $\begin{array}{c}\text { Field, } \\
\text { Well } \\
\text { No. }\end{array}$ & $\begin{array}{l}\text { Salinity } \\
\text { gm. }^{-1}\end{array}$ & $\begin{array}{c}\mathrm{Cl}^{-1} \\
\text { ppm }\end{array}$ & $\begin{array}{l}\mathrm{SO}_{4}^{-2} \\
\mathrm{ppm}\end{array}$ & $\begin{array}{c}\left(\mathrm{SO}_{4}^{-2}\right)_{\mathrm{t}} \\
\mathrm{ppm}\end{array}$ & B.S & I.A \\
\hline Zb-11 & 191.80 & 116939 & 547 & 16301 & -15754 & 3.35 \\
\hline Zb-14 & 192.56 & 115200 & 303 & 16058 & -15755 & 1.88 \\
\hline Zb-15 & 177.30 & 105800 & 405 & 14748 & -14343 & 2.82 \\
\hline Zb-17 & 169.80 & 97628 & 463 & 13609 & -13146 & 3.40 \\
\hline Zb-18 & 196.40 & 118000 & 196 & 16449 & -16253 & 1.20 \\
\hline Zb-23 & 196.00 & 120220 & 320 & 16758 & -16438 & 1.90 \\
\hline RU-7 & ---- & 128868 & 216 & 17964 & -17748 & 1.20 \\
\hline RU-8 & 218.00 & 133465 & 268 & 18605 & -18337 & 1.44 \\
\hline RU-9 & 209.00 & 125000 & 458 & 17425 & -16697 & 2.26 \\
\hline RU-13 & 230.00 & 128912 & 322 & 17970 & -17648 & 1.79 \\
\hline RU-29 & 210.00 & 130028 & 335 & 18125 & -17790 & 1.84 \\
\hline RU-36 & 274.30 & 15789 & 350 & 21967 & -21617 & 1.59 \\
\hline R-29 & 226.00 & 110370 & 390 & 15385 & -14995 & 2.5 \\
\hline RU-34 & 209.91 & 125850 & 280 & 17543 & -17263 & 1.6 \\
\hline R-63 & 216.21 & 122710 & 480 & 17105 & -16625 & 2.8 \\
\hline R-85 & 209.36 & 127419 & 250 & 17705 & -17476 & 1.4 \\
\hline R-95 & 181.72 & 109697 & 250 & 15291 & -15041 & 1.6 \\
\hline $\mathrm{R}-127$ & 202.75 & 124500 & 370 & 17355 & -16985 & 2.1 \\
\hline
\end{tabular}

Table 2: Hydrochemical data of Mishraq natural springs (Ref.: Miscony, 1988).

\begin{tabular}{|c|c|c|c|c|c|c|}
\hline $\begin{array}{c}\text { Field, } \\
\text { Well } \\
\text { No. }\end{array}$ & $\begin{array}{c}\text { Salinity } \\
\text { gm.. }\end{array}$ & $\mathbf{C I}^{-\mathbf{1}} \mathbf{p p m}$ & $\begin{array}{c}\mathbf{S O}_{\mathbf{4}}{ }^{-\mathbf{2}} \\
\mathbf{p p m}\end{array}$ & $\begin{array}{c}\mathbf{( S O}_{\mathbf{4}} \mathbf{-}_{\mathbf{~}} \mathbf{\mathbf { }} \\
\mathbf{p p m}\end{array}$ & $\mathbf{B . S}$ & I.A \\
\hline 1 & 1.99 & 266 & 960 & 133.8 & 826 & 717 \\
\hline 2 & 2.82 & 177 & 1609 & 224 & 1385 & 718 \\
\hline 3 & 2.73 & 354 & 1489 & 207.4 & 1282 & 717 \\
\hline 4 & 5.22 & 709 & 2498 & 348 & 2150 & 717 \\
\hline 5 & 2.86 & 354 & 1465 & 204 & 1261 & 718 \\
\hline 6 & 1.38 & 177 & 756 & 106 & 650 & 713 \\
\hline 7 & 1.31 & 354 & 480 & 67 & 413 & 716 \\
\hline 8 & 2.51 & 266 & 865 & 121 & 744 & 714 \\
\hline 9 & 3.00 & 177 & 1777 & 248 & 1529 & 716 \\
\hline
\end{tabular}

For every water analysis, $\left(\mathrm{SO}_{4}\right)_{\mathrm{t}}$ was calculated from its $\mathrm{Cl}^{-1}$ value in parts per million (ppm) and then its B.S and I.A as shown in Tables (1 to 4). Plots of $\log \left(\mathrm{SO}_{4}\right)$ versus $\log (\mathrm{Cl})$ and B.S versus $\log (\mathrm{I} . \mathrm{A})$ of the data are shown in figures (2 to 4$)$. 
Table 3: Hydrochemical data of selected reservoirs fromm different oil fields (Ref.: Oil Exploration Company-Private Communication).

\begin{tabular}{|c|c|c|c|c|c|c|}
\hline $\begin{array}{c}\text { Field, } \\
\text { Well } \\
\text { No. }\end{array}$ & $\begin{array}{l}\text { Salinity } \\
\text { gm. }^{-1}\end{array}$ & $\mathrm{Cl}^{-1} \mathrm{ppm}$ & $\begin{array}{l}\mathrm{SO}_{4}^{-2} \\
\mathrm{ppm}^{-2}\end{array}$ & $\begin{array}{c}\left(\mathrm{SO}_{4}^{-2}\right)_{\mathrm{t}} \\
\mathrm{ppm}\end{array}$ & B.S & I.A \\
\hline \multicolumn{7}{|c|}{ Mishrif Formation } \\
\hline Zb-55 & 216.6 & 143234 & 120 & 19984 & -19864 & 0.6 \\
\hline Zb-36 & 210.7 & 123700 & 340 & 17243 & -16903 & 1.97 \\
\hline NS-1 & 203.9 & 95158 & 2585 & 13265 & -10680 & 19.48 \\
\hline NS-2 & 190.8 & 116814 & 868 & 16283 & -15415 & 5.34 \\
\hline HR-12 & 160.3 & 100615 & 510 & 14025 & -13515 & 3.63 \\
\hline \multicolumn{7}{|c|}{ Yamama Formation } \\
\hline SU-7 & 174.4 & 104128 & 3021 & 14515 & -11494 & 20.81 \\
\hline Zb-49 & 206.0 & 127556 & 401 & 17781 & -17380 & 2.25 \\
\hline LU-2 & 190.1 & 116480 & 370 & 16237 & -15867 & 2.27 \\
\hline NS-3 & 209.3 & 127125 & 1079 & 17712 & -16642 & 6.07 \\
\hline NS-4 & 84.0 & 483397 & 1598 & 6746 & -5148 & 23.68 \\
\hline \multicolumn{7}{|c|}{ Nahar Umar Formation } \\
\hline SU-1 & 180.7 & 108190 & 350 & 15081 & -14731 & 2.32 \\
\hline SU-9 & 202.0 & 121252 & 237 & 16902 & -16665 & 1.40 \\
\hline Zb-1 & 206.5 & 108940 & 436 & 15186 & -14750 & 2.97 \\
\hline \multicolumn{7}{|c|}{ Sargwlu Formation (M. Jurassic) } \\
\hline JQ-1 & 103.7 & 57841 & 2360 & 8063 & -5703 & 29.27 \\
\hline \multicolumn{7}{|c|}{ Qurra China (U. Triassic) } \\
\hline JQ-1 & 270.9 & 138480 & 7059 & 19304 & -12245 & 36.56 \\
\hline & 189.0 & 109658 & 1930 & 15265 & -13335 & 12.68 \\
\hline \multicolumn{7}{|c|}{ Gerli Khana Formation (M. Triassic) } \\
\hline JQ-1 & 49.7 & 27614 & 1071 & 3849 & -2778 & 27.08 \\
\hline \multicolumn{7}{|c|}{ Euphrates Formation } \\
\hline HR-9 & 15.0 & 7458 & 700 & 1039 & -339 & 67.0 \\
\hline HR-13 & 33.4 & 17404 & 734 & 2426 & -1692 & 30.2 \\
\hline HR-8 & 98.9 & 56725 & 3404 & 7907 & -4503 & 43.0 \\
\hline
\end{tabular}




\section{Shuaiba Formation}

HR-12 164.9 100052

576

Table 4: Hydrochemical data of selected natural sulphuroys springs (Ref.: Jamil et al., 1984, Jamil and Al-Aani, 1986).

\begin{tabular}{|c|c|c|c|c|c|c|}
\hline Spring & $\begin{array}{l}\text { Salinity } \\
\text { gm.L }\end{array}$ & $\begin{array}{l}\mathrm{Cl}^{-1} \\
\mathrm{ppm}\end{array}$ & $\begin{array}{l}\mathrm{SO}_{4}^{-2} \\
\mathrm{ppm}\end{array}$ & $\begin{array}{c}\left(\mathrm{SO}_{4}^{-2}\right)_{\mathrm{t}} \\
\mathrm{ppm}\end{array}$ & B.S & I.A \\
\hline Ain Kibrit & 5499 & 855 & 1708 & 119 & $\begin{array}{c}+15 \\
89\end{array}$ & $\begin{array}{c}143 \\
5\end{array}$ \\
\hline Hammam Al-Alil & 872 & 141 & 214 & 20 & $\begin{array}{c}+19 \\
4\end{array}$ & $\begin{array}{c}107 \\
0\end{array}$ \\
\hline Qiyara-1 & 16.45 & 236 & 4620 & 33 & $\begin{array}{c}+45 \\
87\end{array}$ & $\begin{array}{c}140 \\
0\end{array}$ \\
\hline Qiyara-2 & 6.48 & 1164 & 4718 & 162 & $\begin{array}{c}+45 \\
56 \\
\end{array}$ & $\begin{array}{c}291 \\
2 \\
\end{array}$ \\
\hline Qiyara-3 & 7.56 & 437 & 6494 & 61 & $\begin{array}{c}+64 \\
33\end{array}$ & $\begin{array}{c}106 \\
45\end{array}$ \\
\hline Qiyara-4 & 12.37 & 937 & 5445 & 131 & $\begin{array}{c}+53 \\
14 \\
\end{array}$ & $\begin{array}{c}415 \\
6 \\
\end{array}$ \\
\hline Qiyara-5 & 11.51 & 480 & 2346 & 67 & $\begin{array}{c}+22 \\
79\end{array}$ & $\begin{array}{c}350 \\
1\end{array}$ \\
\hline Fat`ha-1 & 23.42 & 1162 & 4973 & 162 & $\begin{array}{c}+48 \\
11\end{array}$ & $\begin{array}{c}306 \\
9\end{array}$ \\
\hline Fat'ha-2 & 29.87 & 1241 & 9351 & 173 & $\begin{array}{c}+91 \\
78 \\
\end{array}$ & $\begin{array}{c}540 \\
5 \\
\end{array}$ \\
\hline Fat'ha-3 & 35.69 & 306 & 5977 & 43 & $\begin{array}{c}59 \\
34\end{array}$ & $\begin{array}{c}139 \\
00\end{array}$ \\
\hline Fat'ha-4 & 29.78 & 283 & 7263 & 39 & $\begin{array}{c}+72 \\
24 \\
\end{array}$ & $\begin{array}{c}186 \\
23 \\
\end{array}$ \\
\hline Fat'ha-5 & 36.32 & 206 & 2101 & 29 & $\begin{array}{c}+20 \\
72 \\
\end{array}$ & $\begin{array}{c}724 \\
4 \\
\end{array}$ \\
\hline Fat'ha-6 & 39.93 & 356 & 7179 & 50 & $\begin{array}{c}+71 \\
29\end{array}$ & $\begin{array}{c}143 \\
58\end{array}$ \\
\hline Fat'ha-7 & 40.70 & 6324 & 6014 & 881 & $\begin{array}{c}+51 \\
33 \\
\end{array}$ & 682 \\
\hline Fat`ha-8 & 23.60 & 7397 & 5900 & 1031 & $\begin{array}{c}+48 \\
69\end{array}$ & 572 \\
\hline Fat'ha-9 & 29.37 & 1828 & 7840 & 255 & $\begin{array}{c}+75 \\
85 \\
\end{array}$ & 309 \\
\hline Fat`ha-10 & 21.54 & 5510 & 5612 & 768 & $\begin{array}{c}+48 \\
44 \\
\end{array}$ & 730 \\
\hline Hit-1 & 31.07 & 16100 & 403 & 2244 & $\begin{array}{c}- \\
184 \\
1\end{array}$ & 17.9 \\
\hline Hit-2 & 18.20 & 7350 & 681 & 1052 & $\begin{array}{c}- \\
344\end{array}$ & 66.4 \\
\hline Hit-3 & 12.33 & 5950 & 186 & 829 & $\begin{array}{c}- \\
643\end{array}$ & 22.4 \\
\hline
\end{tabular}


Hydrogeochemical Indeces for.....

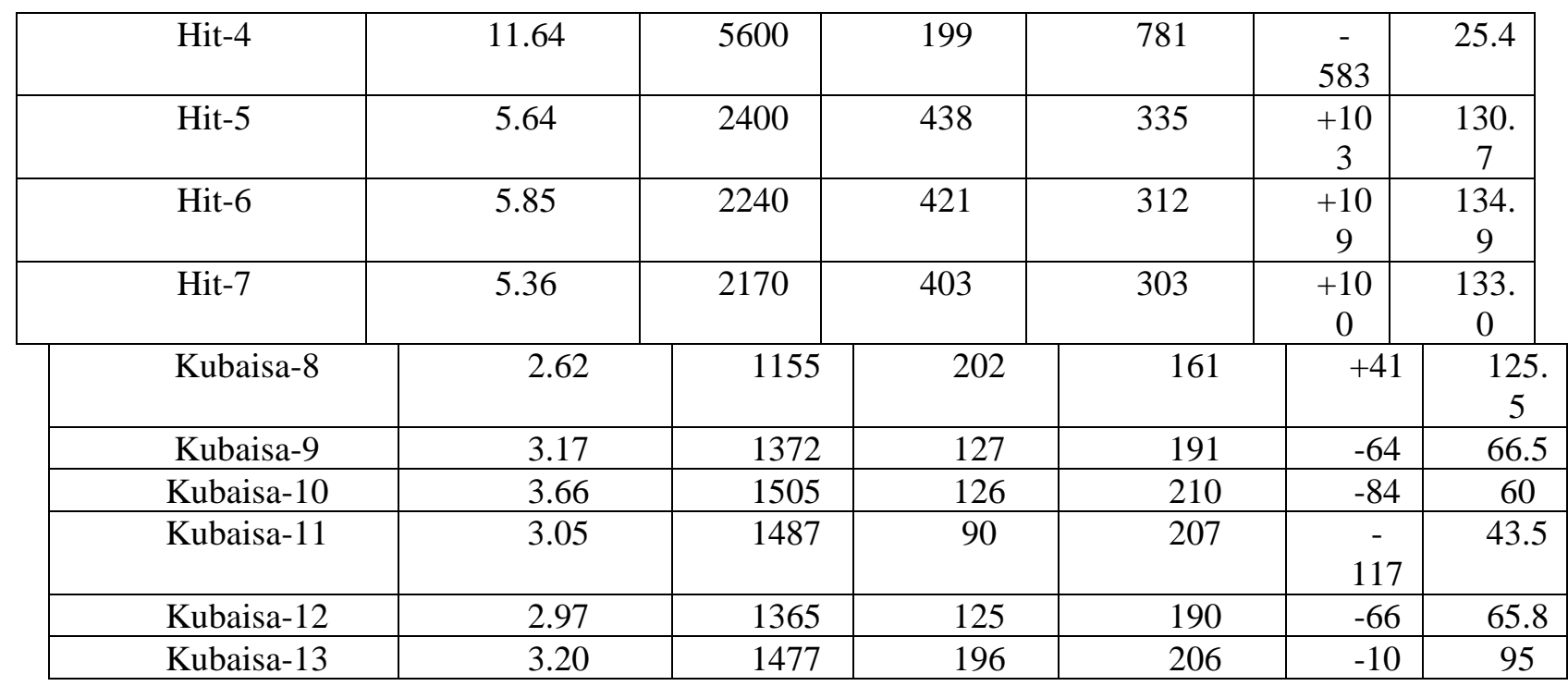


Adil K. Jamil

Tִ.

N

$\frac{0}{0}$

के

웅

2

के

0

छ.

"ृ

음

옹

罟.

के

$\exists$

䨪的

जี

O

$\stackrel{\vec{D}}{\circ}$

$\sum$

可

○ิ

옹

웅

芌

总.

节 
Hydrogeochemical Indeces for.....

Fig. 3: Plots of BS vs log (IA) for some natural waters associated with hydrocarbon and native sulphur deposits in Iraq.

Fig. 4: Plots of $\log \mathrm{Cl}^{-1}$ vs $\mathrm{SO}_{4}^{-2}$ in ppm for some reservoirs and oil fields in Iraq. 


\section{RESULTS, PRESENTATION AND DISCUSSION}

For the examined oil field waters, the B.S values were highly negative and ranged from over -13000 (Zb-17) to more than -21000 (RU-36), while their I.A values were positive and low, less than 10 or even less than 5 . Such criteria are excellent indicative for the presence of hydrocarbons. The position of the data on the $\log \mathrm{Cl}$ versus $\log \mathrm{SO}_{4}$ (Fig.2) fall for below and far away to the right from sea water and its line, while they fall to the left below sea water on the log I.A versus B.S plot

(Fig.3).

For the natural sulphurous springs of Mishraq sulphur deposits, their B.S values were positive in the low range 413 to 1529 and their I.A values were positive and ranged between 713-718 which meant that these sulphurous waters are of good aeration. In fact, they represent waters associated with gypsum or gypsum waters (Fig.2). Similarly, for Ain Kibrit (Mosul) and Mammam Al-Alil.

Applying the above criteria to other oil fields or reservoirs, particularly those that have not yet developed (Table 3 and Fig.4), it was evident that they were divided into two groups:

Group 1: Those with I.A values less than 10 and high negative B.S values, more than -13000 . They represented reservoirs of high potential of oil and their data on the same position of the known giant oil fields.

Group 2: Those with I.A values between 12-67 and B.S values less than $=12000$, represented reservoirs of less oil potential and their data fall parallel to the sea water

line.

For Hit and Kubisa natural sulphurous springs, the B.S values were low and ranged between -1841 to +109 and I.A values roughed between 17.9 to 134.9 indicating waters associated with oil fields of very poor potential (Table 4, Figs.2 and

For Qiyara and Fat'ha natural springs, their B.S values were positively high and ranged between 2072 to more than 9000 and their I.A values were also very high, mostly more than 1000 (Table 4, Fig.2). Such criteria indicate that these sulphurous waters are associated with poor deposits of native sulphur except probably the last four springs at Fat ha with I.A values less than 1000, but their high B.S values make them less promising. It is of interest to note that Qiyara natural springs were thought for a long time associated with an oil field, which is evident now is not true.

\section{CONCLUSIONS}

Oil field water associated with superior potential oil fields gave high negative values for the balance of sulphate (B.S) and very low values for the index of aeration (I.A), usually less than 10 .

Natural waters associated with native sulphur deposits are usually gypsum waters, have high positive B,S values and high I.A values.

The B.S and I.A may be considered very useful geochemical indicators for future explorations of hydrocarbon and native sulphur deposits.

\section{REFERENCES}


Bojarski, L., 1970. Die Antwendung der hydrochemischen Klassifikation bei Sucharbeiten auf Erdoel. Z. Angew. Geol., 16, Berlin, pp.123-125.

Buljan, M., 1962. Nova geochemijska metoda za razlikovanje prirodnihvoda. Croat. Chem. Acta, 23, Zagreb, pp.12-23. Buljan, M., 1963. An aspect of geochemical significance of sea water among the natural waters. Rapp. Et Proc,-Verb. Des reunions de la Commis. Hnt. Expl. Sci. Mer Mediterrane, XVII (3), Paris.

Chebotarev, I. I., 1955. Metamorphism of natural waters in the crust of weathering. Geoche. Cosmochim. Acta, 8, pp. 137-170, 198-212, London. Collins, A.G., 1975. Geochemistry of oil field waters. Elsevier, Amsterdam, 496p. Dabrowski, T.K., 1972. Tracing the direction of underground water flow by hydrochemical method and its utilization for oil prospecting in Poland. Geol. Jb., C2, Hannover, pp.289-301. Jamil, A. K., 1975. Hydrochemistry of brine waters of souther oil fields, Iraq. Part 1 and 2. Ninth Arab Petrol. Cong., Dubai, 123 (B-3). Jamil, A. K., Al-Biaty, H.J. and Ali, A.A., 1984. Hydrochemistry of Tigris River, Iraq. J. Water Resources, 3, No.2, Baghdad, pp.73-85. Jamil, A. K., 1978. Hydrochemical and hydrodynamic zones and the probable direction of water flow within Zubair Reservoir of Zubair and Rumaila oil fields, S. Iraq.

Geol. Jb., D25, Hannover, pp.199-211.

Jamil, A.K. and Al-Ani, S.A., 1986. Hydrochemistry of natural springs extending fron Hit to Samawa, W. Desert, Iraq. Poc. $4^{\text {th }}$ Sci. Conf. Res. Sci. Council: 1, Part 1, Baghdad, pp.490-504. (in Arabic)

Miscony, H. S., 1988. Geochemistry and hydrochemistry of native sulphur deposits in Mishraq. Unpub. M.Sc. Thesis, Univ. of Bghdad, 114p. (in Arabic). Sulin, V. A., 1946. Water of petroleum in the system of natural waters. Gostopteknizdat, 